\title{
PEMBELAJARAN SEJARAH YANG EFEKTIF (SURVEI DI SEKOLAH-SEKOLAH TEMPAT PKM/PPL PROVINSI DKI JAKARTA)
}

\author{
Corry Iriani R.
}

\begin{abstract}
Abstrak
Tujuan penelitian ini adalah untuk mendapatkan data empiris mengenai pembelajaran yang efektif dari sudut pandang peserta didik maupun dari sudut pandang guru. Penelitian ini merupakan penelitian kuantitatif menggunakan metode survei. Populasi dalam penelitian ini seluruh siswa kelas X dan XI IPS tempat dilaksanakannya PKM/PPL. Sampel terdiri dari guru dan siswa yang masing-masing jumlahnya 23 orang dan 521 orang. Instrumen yang digunakan berupa angket skala Likert. Hasil penelitian menunjukkan bahwa antara siswa dan guru punya perspektif yang cenderung sama mengenai pembelajaran sejarah yang efektif. Perbedaan yang terjadi hanya dalam hal penggunaan buku paket. Siswa berpandangan penggunaan buku paket efektif untuk pembelajaran sejarah. Sementara guru berpandangan efektifnya pembelajaran sejarah jika juga menggunakan buku selain buku paket.
\end{abstract}

Keyword: Pembelajaran, sejarah, efektif, sekolah tempat PKM/PPL, DKI Jakarta

\section{Pendahuluan}

Sejarawan Notosusanto menyatakan bahwa guna sejarah itu terdiri atas; memberi pelajaran, memberi inspirasi, dan memberi kesenangan. ${ }^{1}$ Bahkan bagi kehidupan bangsa nilai guna sejarah adalah membentuk karakter bangsa. Demikian pentingnya nilai guna sejarah sehingga Soekarno pernah berkata "jangan sekali-kali melupakan sejarah."2

Wineburg bahkan mengingatkan bahwa sejarah memiliki potensi untuk menjadikan kita manusia yang berprikemanusiaan. ${ }^{3}$ Nampak bahwa dengan belajar sejarah dapat menumbuhkan nilai-nilai kemanusiaan dalam diri seseorang. Artinya dalam belajar sejarah sekaligus memanusiakan manusia. Sesuatu yang sangat esensial dalam konteks pendidikan, terlebih lagi ditengah arus globalisasi yang cenderung kehidupan manusia bersifat "hedonisme." Hal itu sejalan dengan apa yang dikemukakan Buchori bahwa pendidikan bukan hanya sekadar menyiapkan peserta didik menjadi tenaga yang siap pakai di pasar kerja, tetapi lebih jauh harus

\footnotetext{
${ }^{1}$ Nugroho Notosusanto. Sejarah dan Sejarawan, (Jakarta: Balai Pustaka, 2000), h. 18-21.

${ }^{2}$ Jangan Sekali-kali meninggalkan Sejarah!, Pidato Presiden Soekarno pada hari ulang tahun Republik Indonesia 17 Agustus 1966, Jakarta, PN Percetakan Negara RI, 1966.

${ }^{3}$ Sam Wineburg. Berpikir Historis Memetakan Masa Depan Mengajarkan Masa Lalu, terjemahan Masri Maris, (Jakarta: Yayasan Obor, 2006), h. 6.
} 
membantu peserta didik untuk menjadi manusia. ${ }^{4}$ Menjadi manusia dalam konteks pendidikan itu berarti adanya suatu upaya yang dilakukan secara sadar dan terarah agar potensi yang terpendam dalam peserta didik dapat ditumbuh-kembangkan menjadi manusia yang baik dan ideal.

Pada sisi yang lain Cicero sebagai dikutip Hamid mengatakan bahwa barang siapa yang tidak mengenal sejarahnya akan tetap menjadi anak kecil. ${ }^{5}$ Cicero makin mengingatkan kita betapa sejarah amat penting dalam proses pendewasaan seseorang. Sehingga pantaslah dalam kehidupan suatu bangsa kalau perilaku masyarakat masih seperti anak kecil maka bangsa itu belum dapat disebut sebagai bangsa sudah maju. Sebab kemajuan suatu bangsa dapat dilihat dari cara berpikir mereka yang tidak kekanak-kanakan seperti anak kecil, tetapi cara berpikir yang rasional, logis dan berdasarkan bukti.

Potensi yang dimiliki manusia sebagaimana diungkapkan di atas dapat berupa potensi rohaniah dan jasmaniah. ${ }^{6}$ Potensi tersebut merupakan kecerdasan yang dimiliki manusia. Namun apapun bentuk kecerdasan yang dimiliki seseorang, pada dasarnya kecerdasan itu bukanlah sesuatu yang statis, tetapi selalu berkembang (dinamis). Perkembangan tersebut berlangsung sejak masa kanak-kanak sampai dewasa. Oleh karena itu bagi Chatib kecerdasan seseorang adalah proses kerja otak seseorang sampai orang itu menemukan kondisi akhir terbaiknya. ${ }^{7}$ Bagaimana berkembangnya kecerdasan seseorang itulah yang bakal diasah dalam proses pembelajaran di sekolah dengan berbagai pelajaran termasuk sejarah. Sehubungan dengan itu Hasan menyatakan bahwa yang harus dilakukan dalam pendidikan sejarah adalah mengembangkan kondisi memori biasa (ordinary memory) peserta didik yang menyimpan fakta sejarah ke arah memperkaya memori cerdas (intelligent memory), sebab memori cerdas menyimpan kemampuan berpikir cerdas dan kritis. ${ }^{8}$

Masalah yang terjadi di sekolah adalah pembelajaran sejarah secara umum berlangsung hanya sebatas pengetahuan, suatu kemampuan berpikir tingkat rendah. Padahal mestinya lebih 2001), h. 9.

${ }^{4}$ Shindunata, "Kata Pengantar," dalam Mochtar Buchori Pendidikan Antisipatoris (Yogyakarta: Kanisius,

5 Abd. Rahman Hamid. Pembelajaran Sejarah, (Yogyakarta: Ombak, 2014), h. 45.

${ }^{6}$ Muhmidayeli, Teori-Teori Pengembangan Sumber Daya Manusia dalam Pendidikan (Bandung: Refika Aditama, 2014), h 5.

${ }^{7}$ Munif Chatib, Sekolahnya Manusia Sekolah Berbasis Multiple Intelligences di Indonesia (Bandung: Kaifa Learning, 2009), h. 69.

${ }^{8}$ Hamid Hasan, Pendidikan Sejarah Indonesia Isu dalam Ide dan Pembelajaran, ed. Agus Mulyana (Bandung: Rizqi Press, 2012), h. 129.

299 | Seminar Nasional Sejarah ke 4 Jurusan Pendidikan Sejarah Universitas Negeri Padang 
dikembangkan kemampuan tingkat berpikir lebih tinggi, seperti menganalisis atau bahkan sampai mengevaluasi. Mengevaluasi itu dalam proses pembelajaran termasuk atribut berpikir kritis yang disebut pemberian pertimbangan. ${ }^{9}$ Evaluasi itu tentunya didukung bukti-bukti yang dapat dipertanggungjawabkan secara ilmiah dan valid. Artinya kalau kemampuan yang demikian itu dikembangkan dalam pembelajaran sejarah, pembelajaran sejarah akan memberi manfaat dan makna bagi kehidupan peserta didik dalam dunia nyata mereka sehari-hari. Namun, karena pembelajaran sejarah cenderung bersifat hafalan itu maka belajar sejarah bagi peserta didik tidak memperoleh makna atau manfaat bagi kehidupannya. Akibatnya pembelajaran sejarah menjadi tidak menarik, membosankan, diabaikan, bahkan dilecehkan dengan perilaku anak yang tidak memperhatikan gurunya dalam proses pembelajaran.

Pembelajaran yang berlangsung di dalam kelas ditentukan oleh bagaimana guru merancang dan melaksanakannya. Guru merupakan unsur yang menentukan efektif tidaknya pembelajaran. Efektifnya pembelajaran menjadi tanda mengenai seorang guru yang baik dan profesional. Kenyataannya juga menunjukkan terdapat kondisi yang berbeda-beda mengenai apa pembelajaran yang efektif. Cukup sulit sebenarnya menggambarkan tentang seorang guru yang efektif karena berkaitan dengan berbagai dimensi yang lebih individual dan jarang teramati. Belum lagi terkait dengan subjek pembelajaran yang bisa jadi antara satu guru dengan guru yang lain berbeda pemahamannya. Begitu juga dari sisi peserta didik apakah ketika mereka memperoleh nilai lalu punya pandangan bahwa pembelajaran sudah efektif atau apakah ketika mereka mampu mengambil makna pembelajaran sejarah dalam kehidupannya sehingga mereka menganggap sudah efektif.Oleh karena itu menjadi menarik untuk mengetahui perspektif guru dan peserta didik mengenai efektifitas pembelajaran sejarah.

Tujuan dari penelitian ini adalah untuk mendapatkan data empiris mengenai pembelajaran yang efektif dari sudut pandang peserta didik maupun dari sudut pandang guru.

\section{Hakekat Pembelajaran Efektif}

Pembelajaran efektif merupakan hal yang sangat esensial dalam proses pembelajaran. Pembelajaran efektif bila proses pembelajaran yang dilaksanakan guru di

\footnotetext{
${ }^{9}$ Ibid., h. 132.
}

300 | Seminar Nasional Sejarah ke 4 Jurusan Pendidikan Sejarah Universitas Negeri Padang 
dalam kelas bisa mencapai tujuan yang telah ditetapkan. ${ }^{10}$ Hal yang sama dikemukakan juga oleh Kyriacou yang menyatakan pembelajaran efektif merupakan pembelajaran yang berhasil mencapai tujuan. ${ }^{11}$ Pembelajaran efektif adalah pembelajaran dimana siswa memperoleh keterampilan-keterampilan yang spesifik, pengetahuan dan sikap serta merupakanpembelajaran yang disenangi siswa. ${ }^{12}$ Dengan demikian nampak bahwa pembelajaran efektif merupakan pembelajaran yang memperlihatkan terjadinya perubahan pada aspek kognitif, afektif, dan psikomotorik sesuai dengan tujuan yang mau dicapai.

Kyriacou lebih lanjut menjelaskan bahwa ada dua unsur yang menentukan pembelajaran efektif yaitu; (1) guru harus mempunyai gagasan tentang apa pembelajaran yang mau dikembangkan, dan (2) terdapatnya suatu pengalaman belajar yang disusun dan disampaikan untuk mencapai hal tersebut. Apa yang dikemukakannya itu memperlihatkan pentingnya peran guru dalam mengembangkan pembelajaran efektif. Guru sejak awal sudah harus merancang bagaimana pembelajaran yang mau diterapkan didalam kelas dapat berlangsung efektif.

Formwalt menyatakan bahwa agar pembelajaran sejarah berlangsung efektif terdapat tujuh prinsip yang harus diperhatikan seorang guru. ${ }^{13}$ Pertama, antusias. Seorang guru harus bersemangat, mampu memberi inspirasi bagi peserta didik, mencintai profesi, menguasai subjek dan selalu belajar tentang subjek setiap hari, dan harus membuat apa yang diajarkan merupakan bagian dari diri. Kedua, sedikit ketergantungan pada buku teks. Seorang guru menjadikan buku teks hanya sebagai panduan, ia harus menggunakan sumber-sumber lain terutama sumber primer. Pilihlah sumber yang memiliki dampak besar yang tidak hanya menginspirasi peserta didik, tetapi guru juga akan mengajar dengan penuh semangat. Ketiga, gunakan sumber sekunder yang bagus. Seorang guru harus menggunakan sumber sekunder yang mampu memberikan kontekstualisasi materi agar peserta didik memahami latar dalam memanfaatkan sumber primer. Keempat,

${ }^{10}$ file.upi.edu/Direktori/FIP/JUR._Psikologi/196605162000122-HERLINA/BELAJAR_EFEKTIF .pdf di akses tanggal 4 Maret 2017.

${ }^{11}$ Chris Kyriacou. Effective Teaching In Schools Theory And Practice, (Cheltenham: Nelson Thorn Ltd, 2009), h. 7.

${ }^{12}$ https://tedjo21.files.wordpress.com/2009/09/ctl.pdf di akases tanggal 4 Maret 2017.

${ }^{13}$ Lee W. Formwalt. "Seven Rules For Effective History Teaching Or Bringing Life To The History Class," OAH Magazine Of History, http://www.oah.org/pubs/magazine/wwl/formwalt. html di akses tanggal 5 Mei 2016.

301 | Seminar Nasional Sejarah ke 4 Jurusan Pendidikan Sejarah Universitas Negeri Padang 
perhatikan hal-hal penting yang terjadi saat ini. Seorang guru mesti peka terhadap permasalahan yang terjadi hari ini, bukan hanya memikirkan apa yang terjadi di masa lampau. Berpikir dalam konteks kekinian dalam rangka mampu mengidentifikasi diri. Kelima, gunakan sebanyak mungkin sejarah lokal. Seorang guru dalam melaksanakan pembelajaran mesti mampu melihat perkembangan sejarah yang terwujudkan ke dalam konteks sejarah lokal. Apa yang terjadi di tingkat nasional mestinya mampu diwujudkan guru dalam konteks sejarah lokal. Keenam, gunakan musik dan film yang menarik. Seorang guru mampu menyentuh emosi peserta didik dengan memutar musik yang sesuai dengan topik yang sedang dibahas atau membuat lirik lagu tentang hal tersebut. Begitu juga dengan film, guru bukan berarti menggunakan film untuk menggantikan posisi mengajar, tetapi dengan film guru memberitahu apa yang harus dicari dari sebuah film. Terakhir, melek komputer. Seorang guru harus menguasai teknologi komputer, mampu menggunakan laman daring untuk kepentingan pembelajaran. Sebab laman daring dapat memperkaya pengetahuan. Tetapi perlu diperhatikan laman yang dicari secara daring itu haruslah yang dapat diandalkan, bukan sumber yang tidak dapat dipercaya.

Sedangkan Seifert berpandangan bahwa pembelajaran dapat berlangsung efektif apabila pembelajaran dalam kelas sedapat mungkin bisa menerima situasi dan gagasan baru, memaksimalkan tentang apa saja yang sudah dipelajari peserta didik, dan merancang tujuan pembelajaran yang berorientasi pada perilaku. ${ }^{14}$

Pada sisi yang lain dari segi situasi komunikasi Minnick mengemukakan bahwa pembelajaran efektif apabila terdapat unsur-unsur berikut ini yaitu; (1) model komunikasi, (2) latar suasana, (3) pendengar, (4) pesan, (5) media pendukung, (6) penyampaian, dan (7) umpan balik. ${ }^{15}$ Model komunikasi adalah keseluruhan mengenai proses / cara berkomunikasi dan menyediakan konsep dasar kerangka kerja untuk menganalisis situasi komunikasi. Latar suasana adalah bagaimana bentuk penyampaiannya, jenis media, keadaan perasaan, harapan dan tingkah laku peserta didik. Pendengar maksudnya adalah menyampaikan topik dan cara bagaimana topik tersebut harus dibahas. Pesan adalah hal yang mempengaruhi bentuk pembelajaran dan media

\footnotetext{
${ }^{14}$ Kelvin Seifert. Pedoman Pembelajaran \& Instruksi Pendidikan, terjemahan Yusuf Anas, (Yogyakarta, IRCiSoD, 2012), h. 171-172.

${ }^{15}$ Dan R Minnick. Panduan Pengajaran Yang Efektif, terjemahan Dyah Sarastri, (Jakarta: Sekretariat Bina Desa, 2001), h. 1-2.
}

302 | Seminar Nasional Sejarah ke 4 Jurusan Pendidikan Sejarah Universitas Negeri Padang 
yang digunakan. Media pendukung maksudnya adalah hal yang mendukung pembelajaran berupa media gambar atau suara (audio). Penyampaian berkaitan dengan bagaimana cara penyampaian pesan dilakukan. Sedangkan umpan balik maksudnya adalah suatu cara mendapatkan masukan dari peserta didik dan berguna untuk menselaraskan informasi yang disampaikan.

Oleh karena itu maka guru dalam pembelajaran perlu memperhatikan dimensi berikut; (1) etos, (2) pembelajaran langsung, (3) manajemen materi, (4) praktek terbimbing, (5) komunikasi terstruktur, (6) memantau, (7) manajemen prosedur atau sistem, (8) perencanaan, dan (9) evaluasi. ${ }^{16}$ Etos maksudnya guru memahami adanya perbedaan kebiasaan peserta didik, peserta didik mampu mengintrospeksi diri melalui tugas dan tanggungjawab yang diberikan guru, memahami kemampuan yang dimiliki peserta didik. Pembelajaran langsung berarti guru dalam pembelajaran hendaknya dapat menarik minat, memberi penjelasan yang efisien dan memberikan berbagai contoh yang sesuai dengan keragaman peserta didik. Manajemen materi menuntut guru untuk mampu mengidentifikasi bahan dan sumber yang dibutuhkan, mempersiapkan dan mengelola bahan pembelajaran, dan menggunakan bahan tersebut secara efektif. Praktek terbimbing berarti guru mempersiapkan program praktik yang sesuai dengan apa yang mau dicapai dalam pembelajaran dan dapat memilih latihan-latihan yang tepat buat peserta didik serta meluangkan waktu untuk menanggapi apa yang dikemukakan peserta didik. Komunikasi terstruktur maksudnya agar guru mau mendengar secara baik apa yang dikemukakan peserta didik dan menanggapi dengan sabar, mengenali dan menganalisa kesulitan peserta didik, memperhatikan gagasan peserta didik yang menantang dan menarik perhatian. Memantau menuntut guru untuk memeriksa apakah peserta didik dapat mengikuti dan menyelesaikan pembelajaran, memperhatikan penggunaan waktu, mendeteksi masalah ketertiban lebih awal, serta telusuri pemahaman peserta didik mengenai pembelajaran. Manajemen prosedur atau sistem maksudnya adalah guru berusaha untuk melaksanakan kerangka peraturan dan prosedur yang telah ditetapkan, mengantisipasi kebutuhan dan identifikasi seperangkat peraturan dan prosedur, dan membangun sistem keteraturan berdasarkan peraturan dan prosedur yang tepat. Perencanaan dimana guru merencanakan sumber daya, merencanakan tujuan yang jelas,

${ }^{16}$ Richard Dunne \& Ted Wragg. Effective Teaching, (London: Taylor \& Francis e-Library, 2005), h. 7. 303 | Seminar Nasional Sejarah ke 4 Jurusan Pendidikan Sejarah Universitas Negeri Padang 
merencanakan kegiatan khusus yang melibatkan berbagai keterampilan dan proses intelektual, dan merencanakan program kerja. Evaluasi tertulis yang berarti guru mendeskripsikan secara valid mengenai kinerja dan reaksi peserta didik terhadap pekerjaan, mengevaluasi secara sistematis pekerjaan dengan menggunakan berbagai data, dan menunjukkan pemahaman tentang keragaman prestasi peserta didik.

Penelitian Boadu dengan judul Effective Teaching in History: The Perspectives of History Student-Teachers ${ }^{17}$ dengan menggunakan pendekatan konstruktivis interpretif menunjukkan ada tiga tahapan pembelajaran efektif yang ditemui yaitu tahap pra mengajar, pelaksanaan mengajar, dan paska-pelaksanaan mengajar. Pada tahap pra mengajar guru sejarah harus memperoleh materi pengetahuan, mengetahui peserta didik, mempunyai perencanaan yang memadai, dan dapat bekerja sama dengan guru lain. Pada tahap pelaksanaan mengajar, guru sejarah harus menunjukkan penguasaan terhadap materi pengetahuan, antusias atau bersemangat, mengaitkan materi dengan pengetahuan peserta didik sebelumnya, menggunakan berbagai metode dan sumber untuk pembelajaran, membuat lingkungan belajar yang mendukung, dan menggunakan teknik penilaian alternatif. Pada tahap paska pelaksanaan mengajar, guru terbuka terhadap peserta didik, mencari umpan balik dari peserta didik, dan memperbaharui pengetahuan baik materi maupun pedagogik.

\section{Metode}

Metode yang digunakan dalam penelitian ini adalah metode deskriptif dengan teknik survei.Populasi penelitian seluruh guru yang mengajar dan peserta didik kelas X dan XI IPS tempat lokasi PKM / PPL Provinsi DKI Jakarta. Oleh karena guru dalam penelitian ini jumlahnya tidak mencapai 100 orang maka sampel guru adalah keseluruhan guru yang mengajar di kelas IPS X dan IPS XI. Sedangkan sampel siswa dipilih dengan cara sampel kuota (quota sampling) dimana dari seluruh siswa IPS kelas X dan XI di masing-masing sekolah lokasi PKM/PPL diambil secara proporsional sebanyak 25\%. Atas dasar itu maka diperoleh jumlah sampel guru sebanyak 23 orang dan sampel peserta didik sebanyak 521 orang.

\footnotetext{
${ }^{17}$ Gideon Boadu. "Effective Teaching In History: The Perspectives Of History Student-Teachers," International Journal of Humanities And Social Sciences, Vol. 3 No. 1, http://aajhss.org/index.php/ijhss di akses tanggal 2 Maret 2017.
}

304 | Seminar Nasional Sejarah ke 4 Jurusan Pendidikan Sejarah Universitas Negeri Padang 
Data untuk penelitian ini dikumpulkan dari responden dengan menggunakan instrumen berbentuk angket. Angket tersebut dibuat dalam bentuk skala Likert. Teknik analisis data yang digunakan dalam penelitian ini adalah deskriptif kuantitatif. Data-data yang didapatkan dibuat dalam bentuk tabel frekwensi dan persentase dimana data-data tersebut diklasifikasi berdasarkan jumlah pilihan jawaban yang sama untuk setiap pertanyaan, kemudian membaginya dengan jumlah sampel dan dikalikan dengan persentase.

Hasil dari perhitungan statistik diinterpretasi dengan menggunakan kriteria angka 0-25 \% berarti sangat lemah (kurang), 26-50 \% berartilemah (kurang), 51-75 \% berarti cukup (kurang tinggi) dan76-100\% berarti kuat (tinggi).

\section{Hasil Penelitian}

Hasil survei dalam pembelajaran sejarah mesti berlangsung dalam suasana yang antusias baik peserta didik maupun guru memperlihatkan antusias yang kuat (tinggi) dalam pembelajaran sejarah. Di kalangan peserta didik antusias itu mencapai 97\%. Hanya ada 7\% yang tidak antusias. Sedangkan di kalangan guru memperlihatkan mereka antusias semua dalam menyampaikan pembelajaran sejarah yang mencapai 100\%. Perspektif guru yang mencapai $100 \%$ itu terdiri dari sangat setuju $54.5 \%$ dan setuju $45.5 \%$. Artinya tidak ada guru yang tidak antusias dalam menyampaikan atau melaksanakan pembelajaran sejarah. Hal itu dapat dilihat dari chart berikut ini.

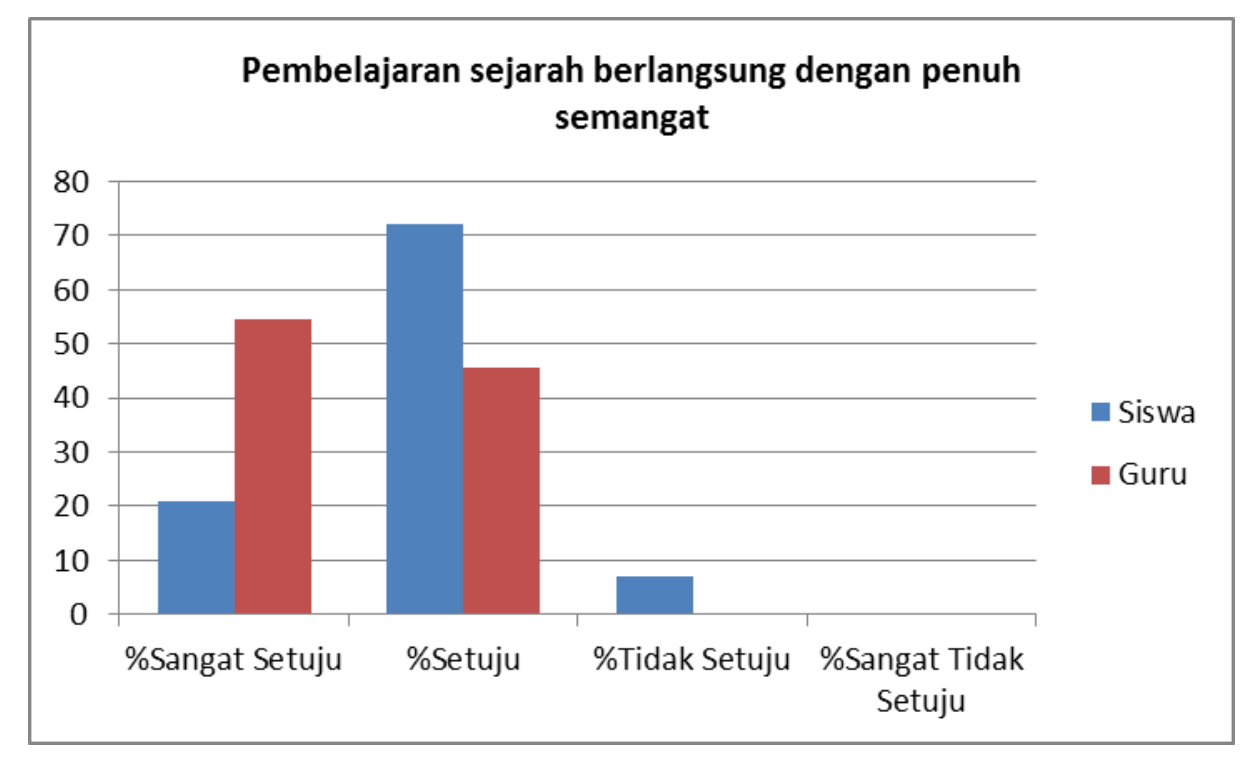

305 | Seminar Nasional Sejarah ke 4 Jurusan Pendidikan Sejarah Universitas Negeri Padang 
Ketika pernyataan dalam bentuk negatif diajukan ternyata hasilnya tetap memperlihatkan antusias yang kuat di kalangan siswa maupun guru dalam pembelajaran sejarah. Hasilnya tergambar dalam chart berikut ini.

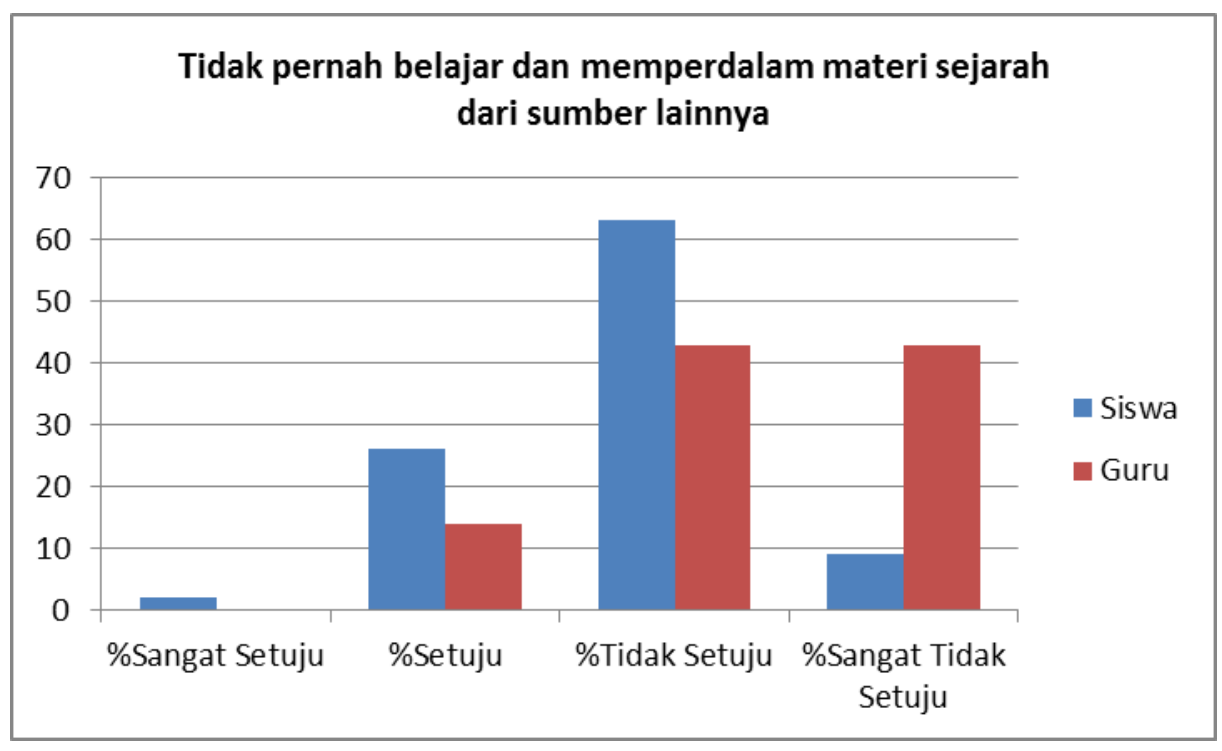

Chart di atas memperlihatkan ada $28 \%$ siswa yang setuju tidak pernah belajar dan memperdalam materi sejarah dari sumber lainnya. Sedangkan yang tidak setuju mencapai $72 \%$. Dengan demikian di kalangan siswa cukup tinggi keinginan untuk membaca dan memperdalam materi sejarah. Sementara di kalangan guru sangat lemah yang tidak pernah belajar dan memperdalam materi sejarah. Jumlahnya mencapai 14\%. Sebaliknya ada $86 \%$ yang kuat keinginan untuk belajar dan memperdalam materi sejarah yakni $43 \%$ tidak setuju dan $43 \%$ sangat tidak setuju.

Efektifnya pembelajaran sejarah terlihat dari sedikitnya penggunaan buku paket. Untuk itu kepada responden diajukan pernyataan negatif mengenai penggunaan buku paket itu. Sehubungan dengan itu terlihat di kalangan siswa ada $40 \%$ yang cenderung setuju dan yang cenderung tidak setuju ada 60\%. Dari $40 \%$ yang cenderung setuju ada $4 \%$ yang sangat setuju dan $36 \%$ setuju. Sedangkan cenderung tidak setuju ada $49 \%$ tidak setuju dan $11 \%$ sangat tidak setuju. Sebaliknya di kalangan guru cenderung setuju ada $76 \%$ dan cenderung tidak setuju $24 \%$. Kecenderungan setuju terdiri dari $17 \%$ sangat setuju dan 59\% setuju. Kecenderungan tidak setuju terdiri dari 15\% tidak setuju dan 9\% sangat tidak setuju. Gambaran tersebut seperti terlihat dari chart berikut ini.

306 | Seminar Nasional Sejarah ke 4 Jurusan Pendidikan Sejarah Universitas Negeri Padang 


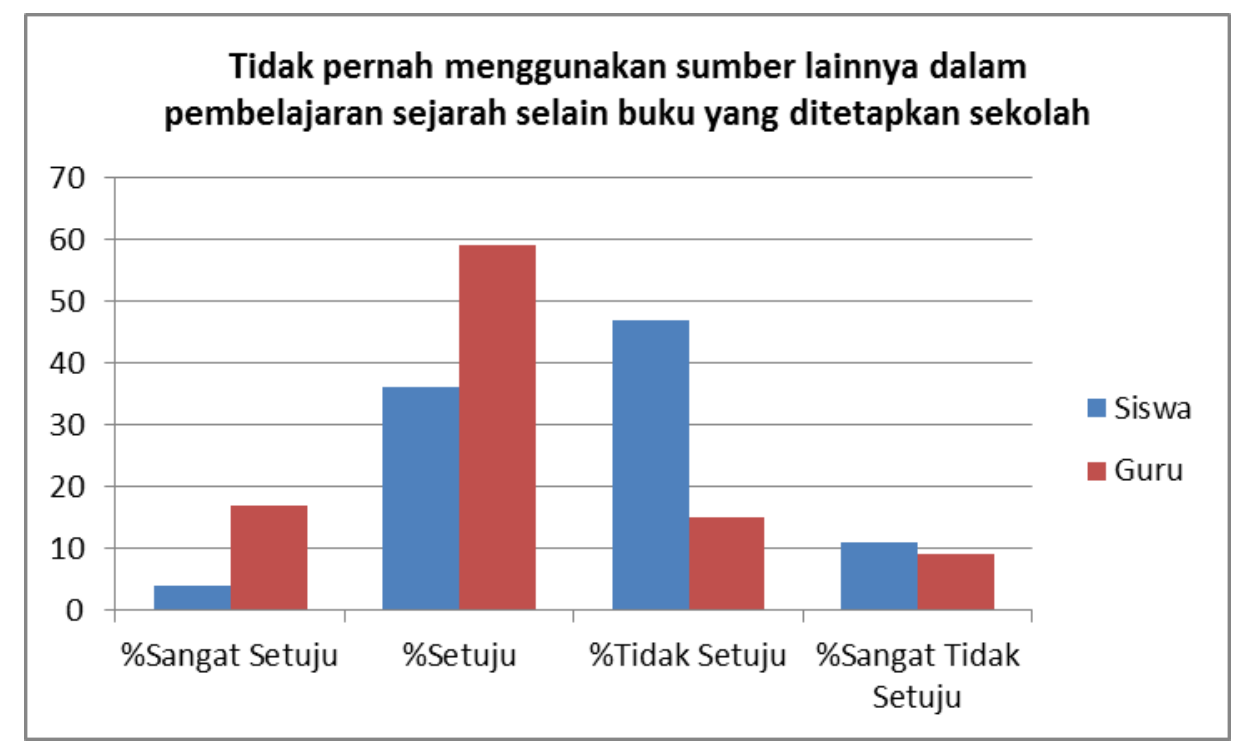

Pada sisi yang lain saat dikemukakan dalam bentuk pernyataan positif tampak kecenderungan setuju sebanyak 64\% dan tidak setuju 36\% di kalangan siswa. Dari 64\% itu ada $6 \%$ sangat setuju dan $58 \%$ setuju. Sedang yang cenderung tidak setuju $36 \%$ terdiri dari $33 \%$ tidak setuju dan 3\% sangat tidak setuju. Dengan demikian baik siswa maupun guru kurang tinggi keinginan menggunakan sumber lainnya dalam pembelajaran sejarah.

Nampaknya di kalangan siswa hal itu sejalan karena cukup kuat pandangan bahwa pembelajaran sejarah efektif ketika selalu menggunakan buku paket seperti terlihat dari chart berikut ini.

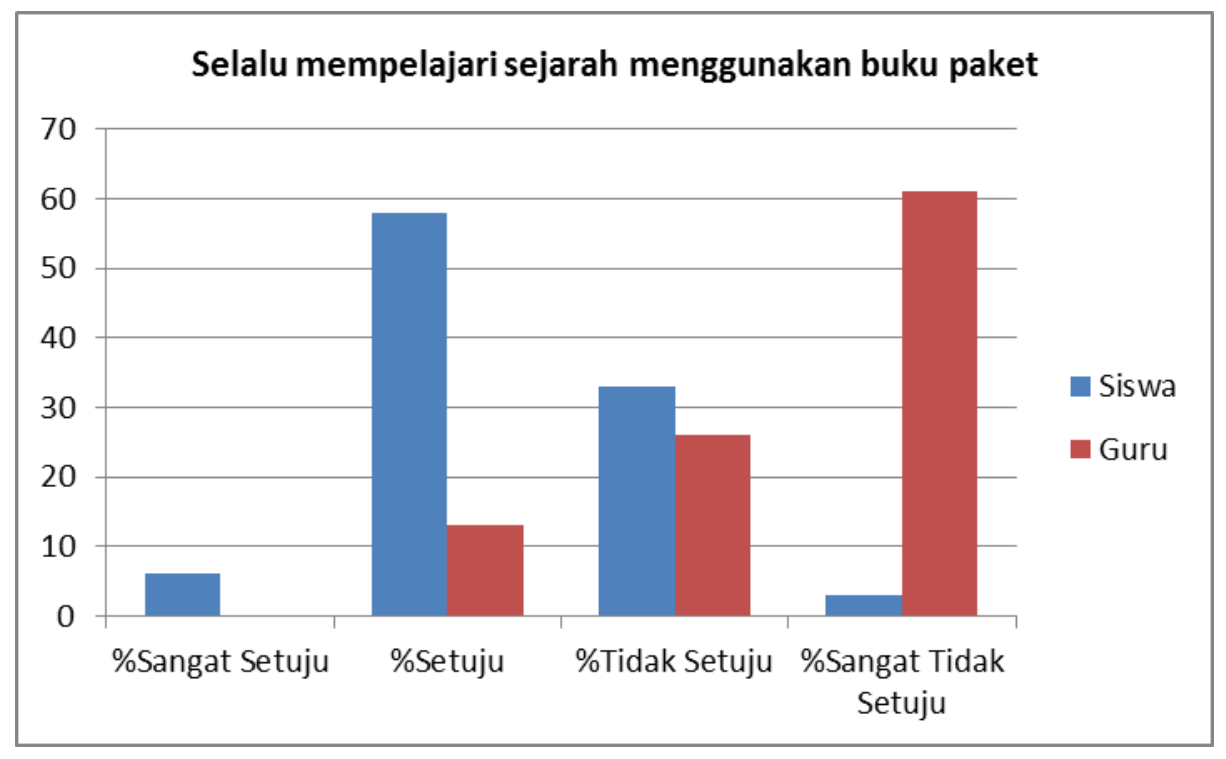

307 | Seminar Nasional Sejarah ke 4 Jurusan Pendidikan Sejarah Universitas Negeri Padang 
Sebaliknya di kalangan guru kecenderungan setuju sebanyak 13\% dan tidak setuju $87 \%$. Pandangan guru dapat dikatakan bertolak belakang dengan pandangan siswa terkait penggunaan buku paket. Dari 13\% yang setuju tidak satupun yang memilih sangat setuju. Sementara yang $87 \%$ tidak setuju ada sebanyak 26\% tidak setuju dan 61\% sangat tidak setuju. Dengan demikian di kalangan guru kuat pandangan tidak menyetujui pembelajaran sejarah yang selalu menggunakan buku paket. Artinya guru berpandangan bahwa pembelajaran sejarah dapat efektif dengan menggunakan sumber belajar selain buku paket.

Pembelajaran sejarah pada dasarnya dapat menggunakan sumber sekunder. Namun agar pembelajaran efektif maka sumber sekunder itu mesti menggunakan sumber sekunder yang bagus. Sehubungan dengan penggunaan sumber sekunder yang bagus itu di kalangan siswa terdapat pandangan yang cukup (kurang) kuat yang mencapai 61\% dengan rincian 9\% sangat setuju dan 52\% setuju. Ada 39\% yang berpandangan tidak setuju terhadap penggunaan sumber sekunder yang bagus. Jadi lemah pandangan di kalangan siswa mengenai penggunaan sumber sekunder yang bagus. Di kalangan guru ada $96 \%$ yang cenderung setuju penggunaan sumber sekunder yang bagus. Artinya kuat di kalangan guru pandangan yang menyebutkan penggunaan sumber sekunder bagus. Sangat lemah pandangan tidak setuju mengenai penggunaan sumber sekunder yang bagus hanya $4 \%$. Lebih jelasnya mengenai penggunaan sumber sekunder itu dapat dilihat pada chart berikut ini.




Akan tetapi penggunaan sumber sekunder yang bagus itu saat pernyataannya dibuat negatif diperoleh gambaran sebagaimana terlihat dari chart berikut ini:

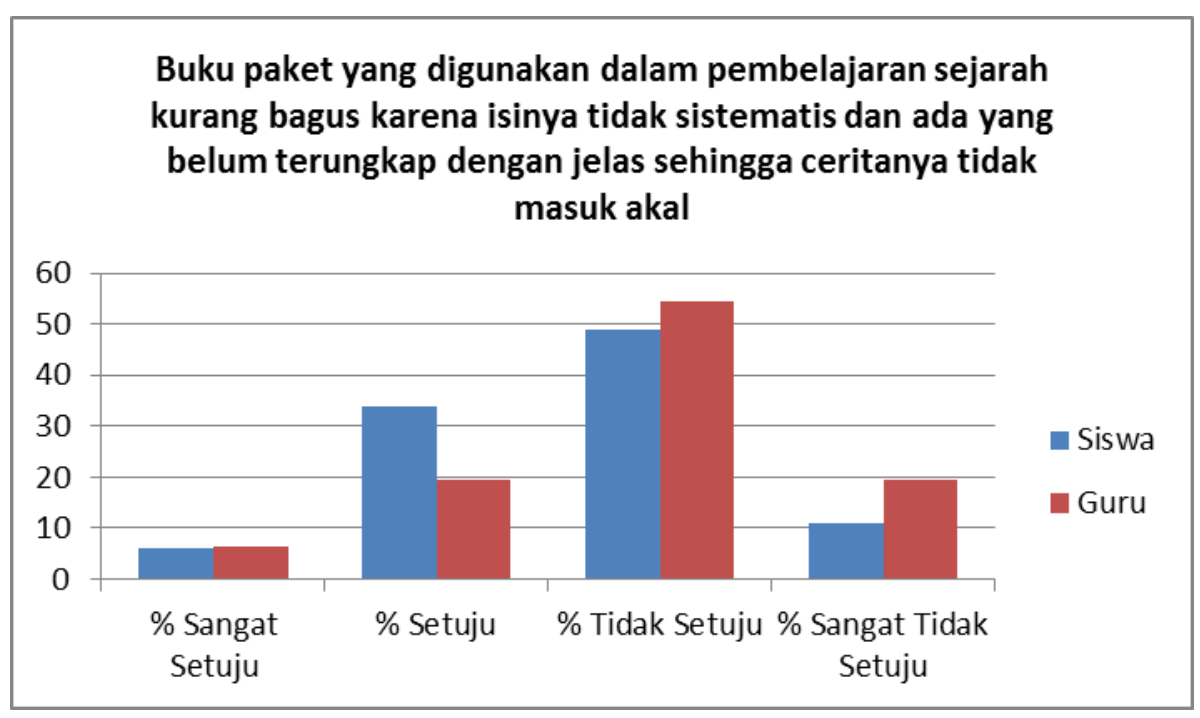

Di kalangan siswa ada $40 \%$ yang cenderung setuju pernyataan di atas. Sementara di kalangan guru ada 26\% jumlahnya. Sebaliknya kecenderungan tidak setuju terhadap pernyataan itu ada $60 \%$ di kalangan siswa dan di kalangan guru ada $74 \%$. Artinya baik siswa maupun guru punya pandangan cukup (kurang tinggi) untuk penggunaan sumber sekunder yang tidak bagus. Dengan demikian penggunaan sumber sekunder yang tidak bagus ditoleren baik oleh siswa maupun guru.

Aspek kepekaan terhadap permasalahan saat ini yang menunjukkan pembelajaran sejarah efektif memperlihatkan hasil sebagai berikut. 


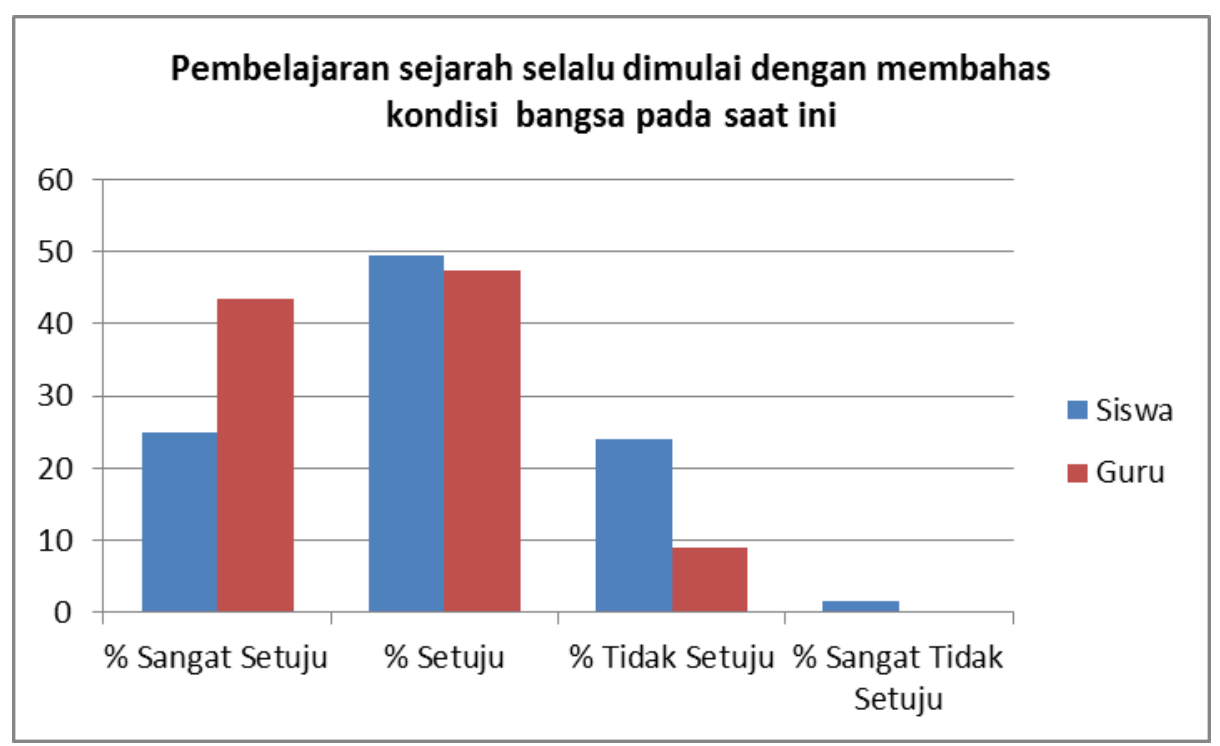

Baik siswa maupun guru sama-sama punya pandangan bahwa pembelajaran sejarah dimulai dengan membahas kondisi bangsa saat ini. Di kelompok siswa yang cenderung setuju mencapai $74.5 \%$ dan tidak setuju ada $25.5 \%$. Sedangkan guru yang cenderung setuju mencapai 91\%. Jadi antara siswa dan guru terdapat sedikit perbedaan terkait memulai pembelajaran sejarah. Bagi siswa sudah cukup (kurang) tinggi kalau pembelajaran sejarah dimulai dengan membahas kondisi saat ini. Sebaliknya bagi guru sudah kuat (tinggi) pandangan bahwa pembelajaran sejarah dimulai dengan kondisi saat ini.

Begitu pernyataan tentang kepekaan terhadap permasalahan saat ini, dibuat negatif diperoleh gambaran sebagai berikut ini. 




Nampaknya siswa dan guru sama-sama menyadari bahwa korupsi merupakan kejadian yang pernah terjadi di masa lalu. Hanya saja di kalangan siswa kepekaan itu kurang tinggi, sementara di kalangan guru kepekaan itu tinggi. Sebab ada $68 \%$ yang setuju di kelompok siswa. Sedangkan di kelompok guru ada sebanyak $87 \%$.

Siswa dan guru mempunyai pandangan yang sama mengenai pembelajaran sejarah mengutamakan sejarah lokal. Siswa dan guru punya pandangan tinggi tentang hal itu karena yang cenderung setuju di kelompok siswa ada $82 \%$ dan di kelompok guru ada $87 \%$. Lemah sekali yang tidak setuju bahwa pembelajaran sejarah mengutamakan sejarah lokal. Di kalangan siswa sangat setuju ada 16\% dan setuju 66\% dan di kalangan guru sangat setuju 39\% dan setuju $48 \%$. Persentase pandangan siswa dan guru itu tergambar dari chart berikut ini. 


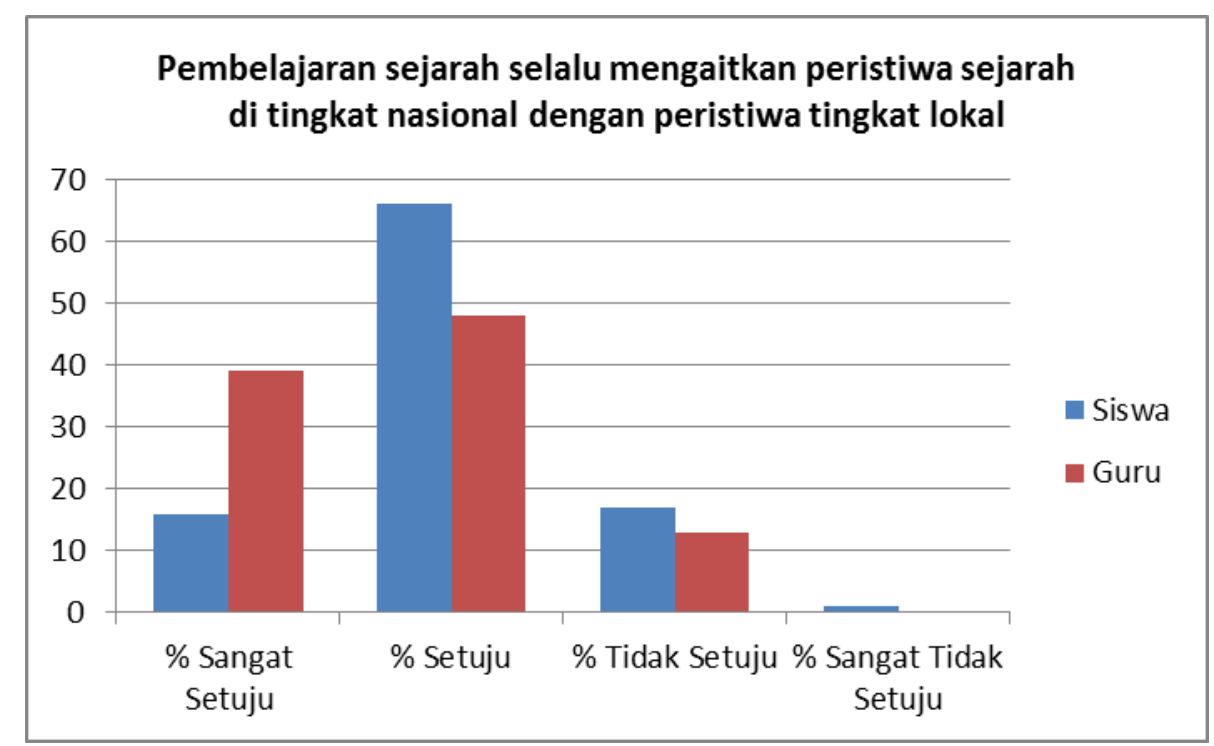

Ketika pernyataan mengenai mengutamakan sejarah lokal dibuat dalam bentuk pernyataan negatif diperoleh pandangan sebagai berikut.

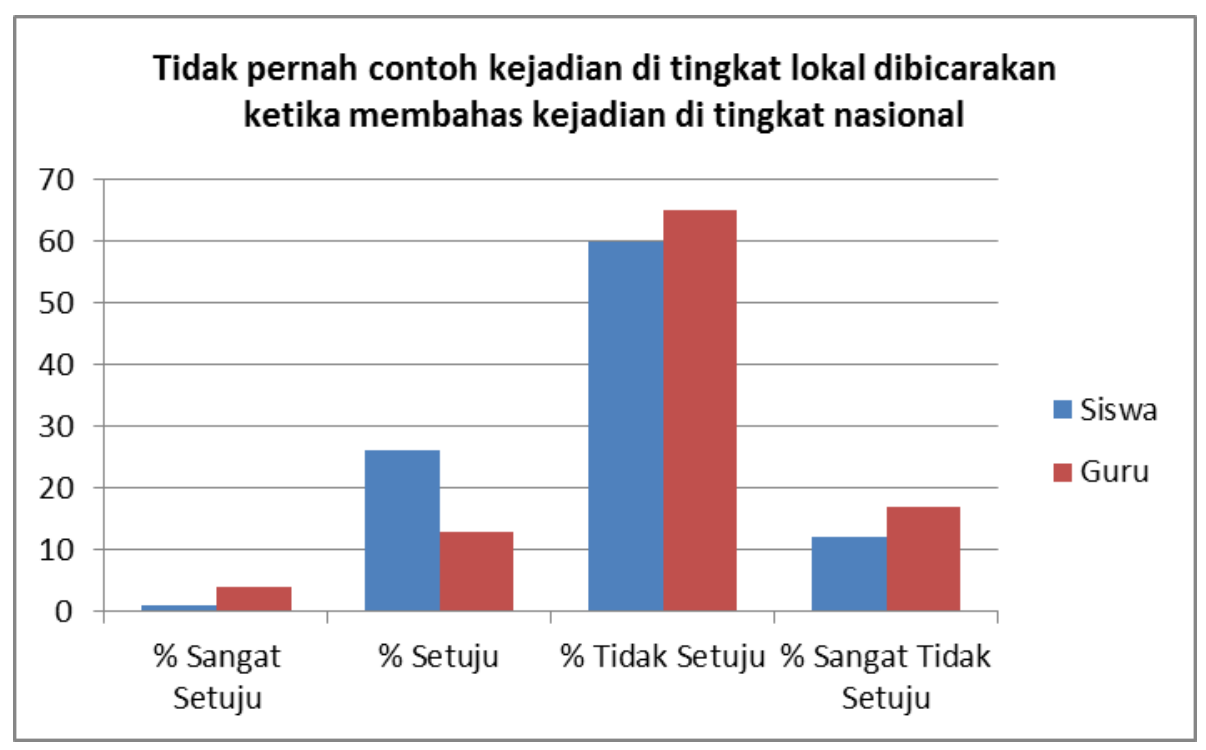

Antara siswa dan guru terdapat perbedaan pandangan mengenai hal itu. Bagi siswa kurang tinggi membahas contoh kejadian di tingkat lokal, sedangkan bagi guru sudah tinggi membahas hal tersebut. Karena terdapat $72 \%$ siswa yang tidak setuju, sementara guru ada $82 \%$ tidak setuju pernyataan tersebut. 
Pembelajaran sejarah berlangsung efektif jika dalam pembelajaran menggunakan musik dan film. Berkenaan dengan itu diperoleh gambaran sebagai berikut.

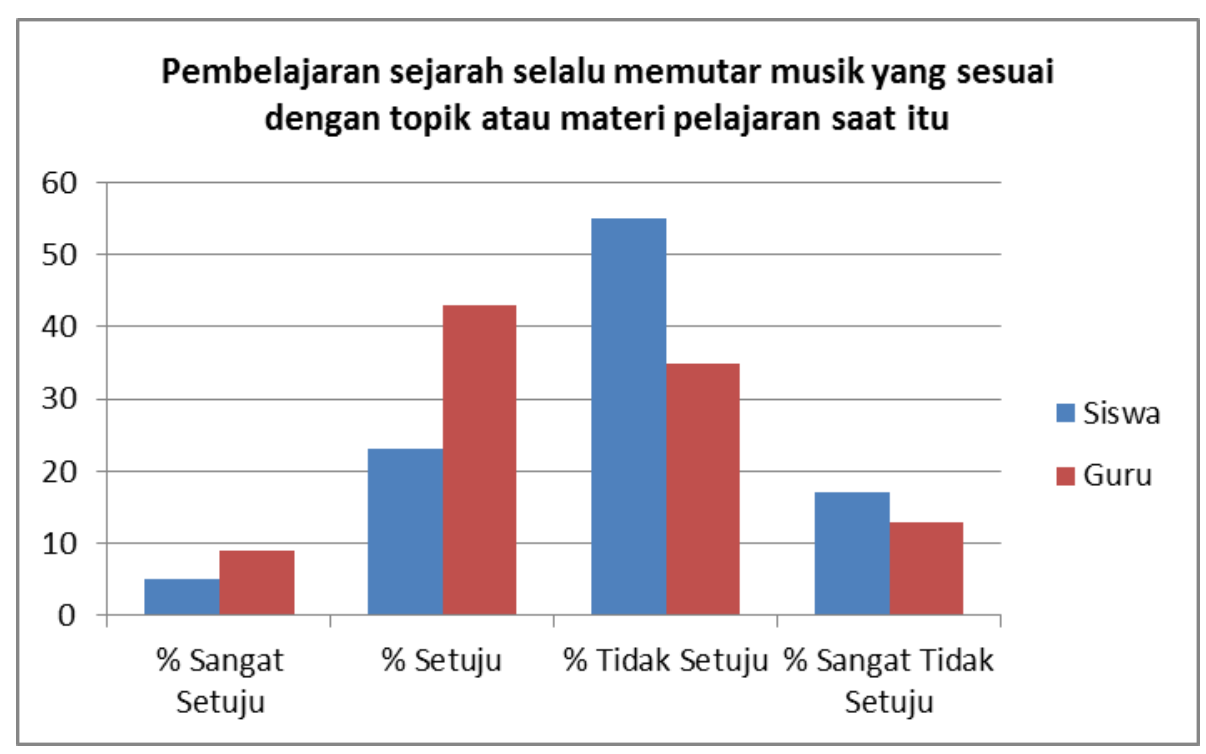

Ada $72 \%$ dari siswa yang tidak setuju dengan pernyataan itu dan $28 \%$ yang menyetujuinya. Dalam pada itu di kalangan guru terdapat $52 \%$ yang setuju dan $48 \%$ yang tidak setuju. Nampaknya siswa berpandangan pembelajaran sejarah selama ini lemah dalam menggunakan musik. Sebaliknya di kalangan guru hasilnya memperlihatkan hampir berimbang antara yang setuju dengan yang tidak setuju. Guru yang setuju mencapai $52 \%$ dan tidak setuju mencapai $48 \%$.

Baik siswa maupun guru punya sama-sama tidak setuju ketika pernyataan terkait penggunaan film dalam pembelajaran. Hal itu tergambar dari chart berikut ini. 


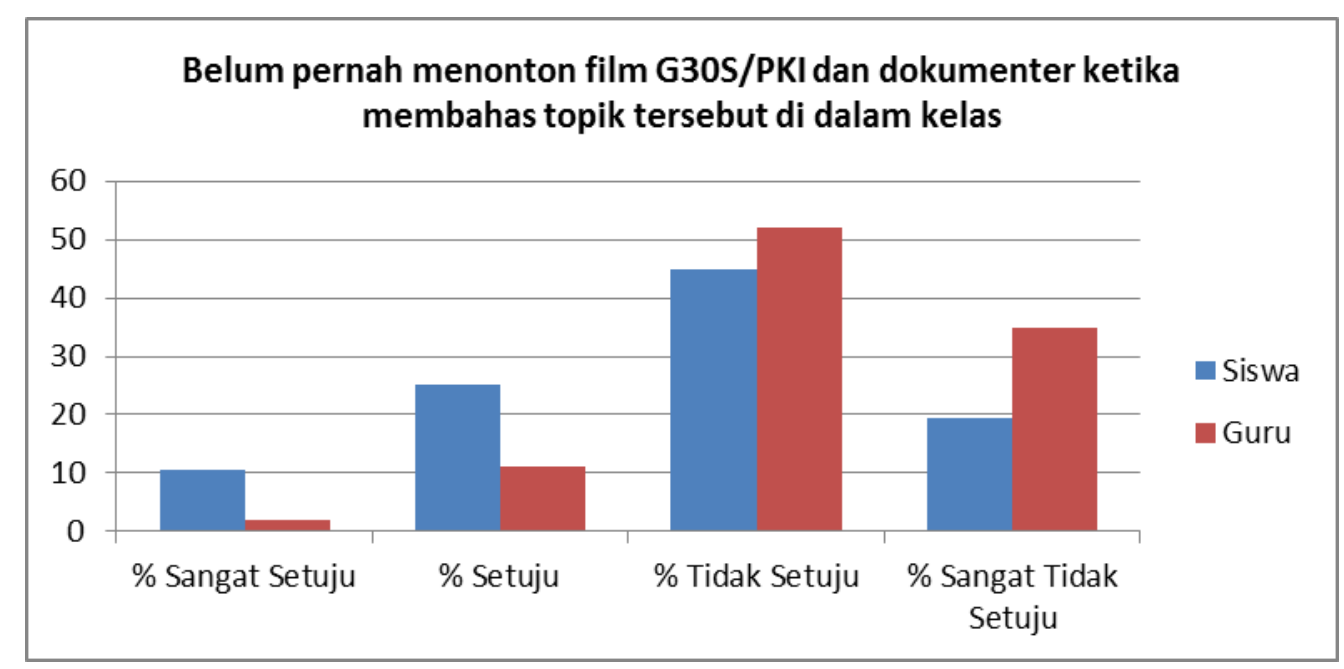

Bagi siswa menonton film sejarah sudah cukup sebab ada $64.5 \%$ yang tidak setuju pernyataan itu. Sedangkan bagi guru sudah tinggi sebab ada $87 \%$ yang tidak setuju dengan pernyataan tersebut. Artinya baik siswa maupun guru sama-sama menunjukkan bahwa film dalam pembelajaran sejarah diperlukan agar pembelajaran berlangsung efektif.

Bahwa dalam pembelajaran sejarah seorang guru harus menguasai teknologi komputer diperoleh jawaban responden sebagaimana terlihat dari chart berikut ini.

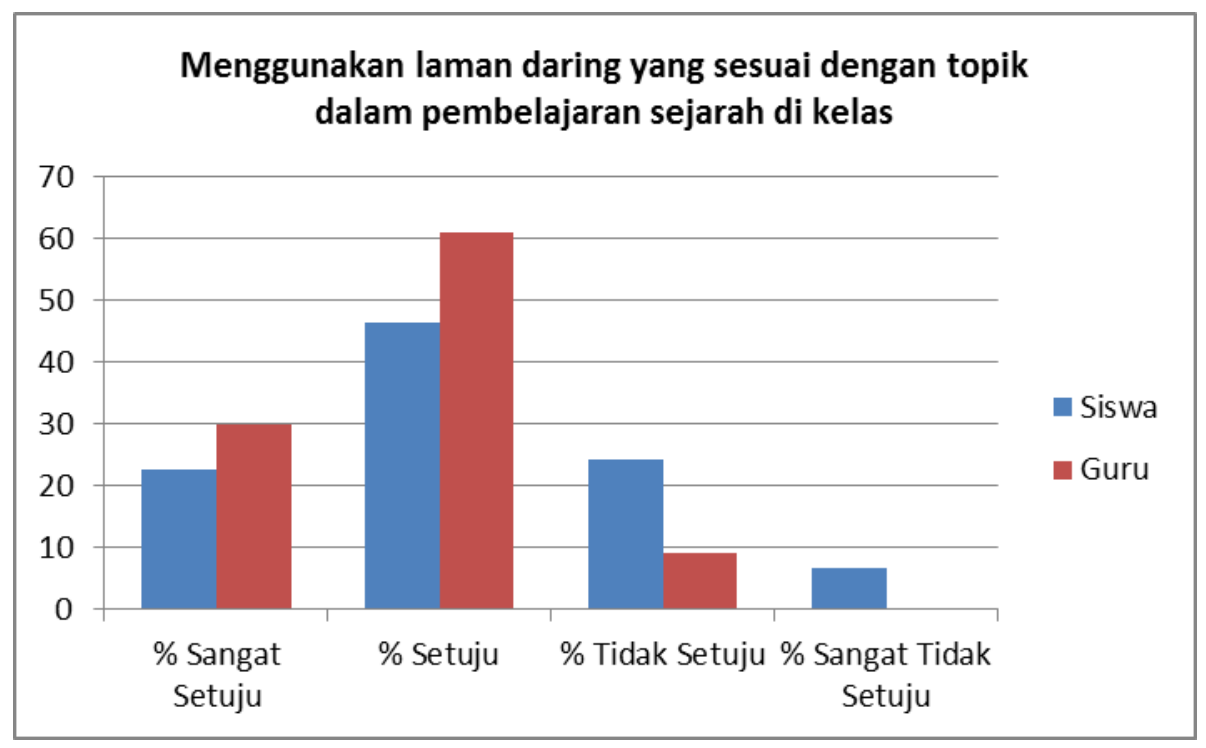

Ada 69\% siswa yang setuju bahwa pembelajaran sejarah menggunakan laman daring. Sementara dari kelompok guru ada $91 \%$ yang setuju menggunakan laman daring. Dengan demikan di kalangan siswa cukup (kurang tinggi) menggunakan laman daring, sedangkan di kelompok guru tinggi penggunaan laman daring dalam pembelajaran sejarah. 
Ketika pernyataan penggunaan laman daring itu dibuat secara negatif baik siswa maupun guru sama-sama memberikan jawaban yang cenderung tidak setuju sebagaimana terlihat dari chart berikut ini.

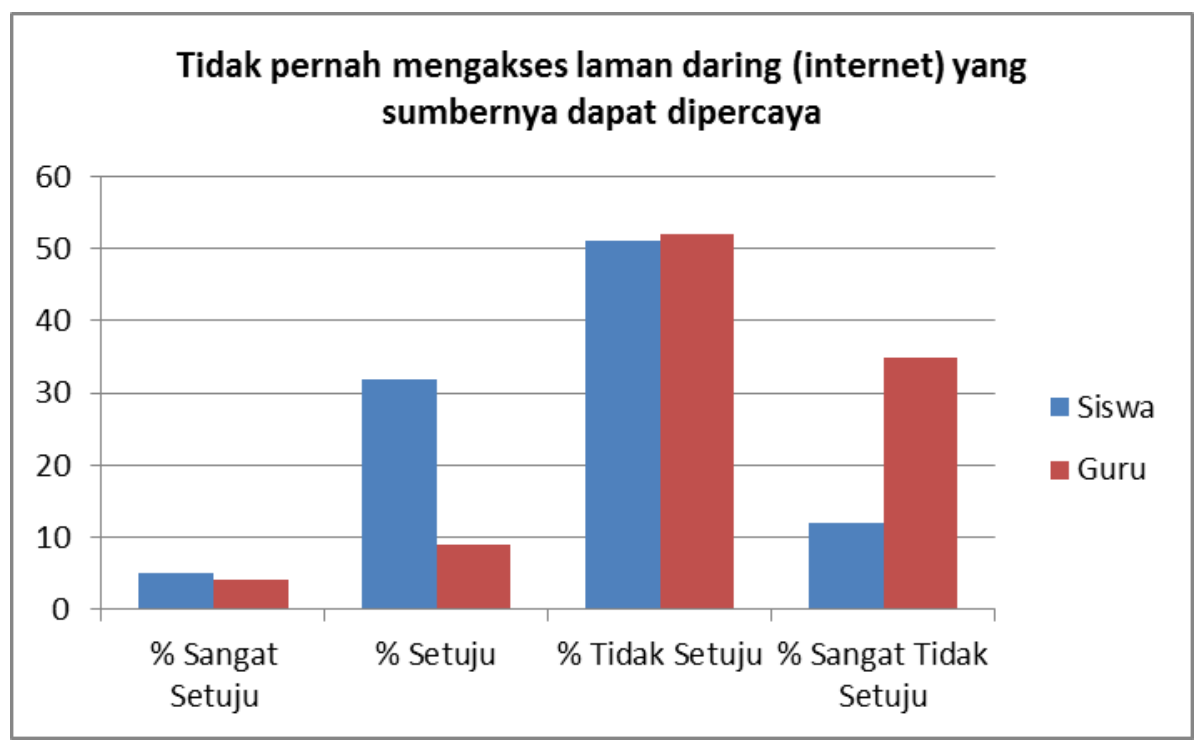

Sebanyak $63 \%$ siswa tidak setuju pernyataan itu dan guru yang tidak setuju ada $87 \%$. Jadi di kelompok siswa ada pada posisi kurang tinggi, sedangkan kelompok guru tinggi tidak pernah mengakses laman daring yang sumbernya dapat dipercaya.

\section{Simpulan}

Hasil survei dengan indikator; antusias, sedikit menggunakan buku paket, penggunaan sumber sekunder yang bagus, peka terhadap kejadian saat ini, mampu melihat perkembangan sejarah dalam konteks lokal, menggunakan musik dan film, dan melek komputer memperlihatkan ada perbedaan pandangan antara peserta didik dan guru mengenai pembelajaran sejarah yang efektif. Di samping terdapat perbedaan, ada juga persamaan pandangan antara peserta didik dengan guru.

Peserta didik dan guru sama-sama berpandangan bahwa pembelajaran sejarah efektif ketika berlangsung dengan penuh semangat. Akan tetapi penuh semangat itu tidak dibarengi dengan penuh semangat juga dalam belajar dan memperdalam materi sejarah. Peserta didik kurang tinggi semangatnya dalam membaca dan memperdalam materi sejarah. Sementara guru membaca dan memperdalam materi sejarah penuh semangat. Hal lain yang menunjukkan 
persamaan pandangan antara peserta didik dan guru adalah dalam hal mengutamakan sejarah lokal. Namun yang menarik dalam hal itu saat saat ditanyakan contoh kasus antara peserta didik dan guru berbeda. Peserta didik punya perspektif kurang tinggi mengenai contoh kasus di tingkat lokal. Dalam pada itu guru punya pandangan yang tinggi mengenai hal itu.

Indikator lainnya dari pembelajaran sejarah yang efektif memperlihatkan terdapatnya perbedaan pandangan antara peserta didik dengan guru. Misalnya guru tinggi ketidaksetujuannya untuk selalu menggunakan buku paket, sementara peserta didik setuju untuk selalu menggunakan buku paket. Dalam hal penggunaan sumber sekunder yang bagus peserta didik kurang tinggi pandangannya mengenai hal itu. Akan tetapi guru berpandangan penggunaan sumber sekunder sudah tinggi.

Pada bagian yang menyangkut kepekaan terhadap permasalahan saat ini baik peserta didik maupun guru menunjukkan ada kepekaan. Hanya saja kepekaan peserta didik kurang tinggi dibandingkan dengan kepekaan guru. Dalam hal penggunaan musik dan film terdapat perbedaan juga. Peserta didik punya pandangan bahwa penggunaan musik dalam pembelajaran sejarah kurang. Sedangkan gurumemperlihatkan kondisi yang hampir berimbang antara yang setuju dengan yang tidak setuju. Sebaliknya dalam hal memanfaatkan film sejarah, baik peserta didik maupun guru sama-sama berpandangan pengunaan film itu diperlukan. Begitu juga dalam hal melek komputer, baik peserta didik maupun guru punya pandangan bahwa laman daring diperlukan dalam pembelajaran sejarah agar berlangsung efektif. Hanya guru berpandangan lebih tinggi sedangkan peserta didik kurang tinggi.

\section{DAFTAR PUSTAKA}

Arikunto,Suharsimi.Manajemen Penelitian, Jakarta: PT. Rineka Cipta, 2000.

Boadu, Gideon. "Effective Teaching In History: The Perspectives Of History Student-Teachers," International Journal of Humanities And Social Sciences, Vol. 3 No. 1, http://aajhss.org/index.php/ijhss di akses tanggal 2 Maret 2017.

Chatib, Munif. Sekolahnya Manusia Sekolah Berbasis Multiple Intelligences di Indonesia, Bandung: Kaifa Learning, 2009.

Dunne, Richard \& Ted Wragg. Effective Teaching, London: Taylor \& Francis e-Library, 2005. 
Formwalt, Lee W. "Seven Rules For Effective History Teaching Or Bringing Life To The HistoryClass,”OAHMagazineOfHistory, http://www.oah.org/pubs/magazine/wwl/formwalt. html di akses tanggal 5 Mei 2016.

Hamid, Abd. Rahman. Pembelajaran Sejarah, Yogyakarta: Ombak, 2014.

Hasan, Hamid.Pendidikan Sejarah Indonesia Isu dalam Ide dan Pembelajaran,ed. Agus Mulyana, Bandung: Rizqi Press, 2012.

Kuntowijoyo. Pengantar Ilmu Sejarah, Salatiga: Tiara Wacana, 2013.

Kyriacou, Chris. Effective Teaching In Schools Theory And Practice, Cheltenham: Nelson Thorn Ltd, 2009.

Minnick, Dan R. Panduan Pengajaran Yang Efektif, terjemahan Dyah Sarastri, Jakarta: Sekretariat Bina Desa, 2001.

Muhmidayeli, Teori-Teori Pengembangan Sumber Daya Manusia dalam Pendidikan, Bandung: Refika Aditama, 2014.

Notosusanto, Nugroho. Sejarah dan Sejarawan, Jakarta: Balai Pustaka, 2000.

Riyanto, Yatim. Paradigma Baru Pembelajaran Sebagai Referensi bagi Pendidik dalam Implementasi Pembelajaran yang Efektif dan Berkualitas, Jakarta: Kencana, 2009.

Shindunata, "Kata Pengantar," dalam Mochtar Buchori Pendidikan Antisipatoris Yogyakarta: Kanisius, 2001.

Seifert, Kelvin. Pedoman Pembelajaran \& Instruksi Pendidikan, terjemahan Yusuf Anas, Yogyakarta, IRCiSoD, 2012.

Sudijono, Anas. Pengantar Statistik Pendidikan, Jakarta: PT Raja Grafindo Persada, 2010.

Soekarno. Jangan Sekali-kali meninggalkan Sejarah!, Pidato Presiden Soekarno pada hari ulang tahun Republik Indonesia 17 Agustus 1966, Jakarta, PN Percetakan Negara RI, 1966.

Wineburg, Sam. Berpikir Historis Memetakan Masa Depan Mengajarkan Masa Lalu, terjemahan Masri Maris, Jakarta: Yayasan Obor, 2006.

file.upi.edu/Direktori/FIP/JUR._Psikologi/196605162000122-HERLINA/BELAJAR_EFEKTIF .pdf di akses tanggal 4 Maret 2017. https://tedjo21.files.wordpress.com/2009/09/ctl.pdf di akses tanggal 4 Maret 2017. 